\title{
Program Di9ital Prayer Time dalam Penentuan Waktu Salat
}

\author{
Fitriyani* $\&$ Syaifur Rizal Fahmy $^{* *}$ \\ Universitas Diponegoro Semarang \& Universitas Islam Negeri \\ Walisongo Semarang \\ Email: yanifitri2483@gmail.com
}

\begin{abstract}
Indonesia still has problems about the time of shalat. This reason that encourage Hendro Setyanto to create a new tool in the form of a display of prayer times of all time with a new concept, Di9ital Prayer Time. This digital clock has been published and has been traded to the public. Thus, this study will examine the method and accuracy of the Di9ital Prayer Time in determining the time of prayer. Regarding this theme, this research is a type of qualitative research using an empirical juridical approach. The specification of this study is descriptive analysis, this study intends to provide an overview, examine, explain then analyze the level of accuracy of the Di9ital Prayer Time in determining the time of prayer. The results of this study indicate that after comparing the Di9ital Prayer Time with the schedule of time for the circular prayer of the Ministry of Religion, only a maximum difference of three minutes was found. If the Di9ital Prayer Time is compared to the results of the program of prayer time by Rinto Anugraha, only a difference of four minutes was found, but after being traced, the program for the Rinto prayer did not yet use ikhtiyat. If the results of the Rinto prayer time program are supplemented by two minutes of faith, the difference is a maximum of two minutes. As such, Di9ital Prayer Time is very relevant as a guideline for prayer times.

* Program Magister Ilmu Hukum Universitas Diponegoro

** Program Magister Ilmu Falak Universitas Islam Negeri Walisongo Semarang
\end{abstract}


60| Fitriyani \& Syaifur Rizal Fahmy

While the determination of the time of prayer by the Indonesian Ministry of Religion which has been the guideline of the people throughout Indonesia is still relevant as a guideline for prayer times. This is still within the limits of relevance, given the schedule of prayer times by the Ministry of Religion is very helpful for the community.

Keywords: Prayer Time, Di9ital Prayer Time, Level of Accuracy

\begin{abstract}
.Abstrak
Indonesia masih terdapat problematika tentang waktu salat. Alasan ini yang mendorong Hendro Setyanto menciptakan alat baru berupa tampilan waktu salat sepanjang masa dengan konsep baru yaitu Di9ital Prayer Time. Jam digital ini sudah dipublikasikan dan sudah diperjualbelikan kepada Masyarakat. Dengan demikian, penelitian ini akan mengkaji tentang metode dan akurasi Di9ital Prayer Time dalam penentuan waktu salat. Terkait dengan tema tersebut, maka penelitian ini termasuk jenis penelitian kualitatif dengan menggunakan pendekatan yuridis empiris. Spesifikasi penelitian ini adalah deskriptif analisis, penelitian ini bermaksud untuk memberikan gambaran, menelaah, menjelaskan kemudian menganalisis tingkat akurasi Di9ital Prayer Time dalam penentuan waktu salat. Hasil penelitian ini menunjukkan bahwa setelah membandingkan Di9ital Prayer Time dengan jadwal waktu salat edaran Kementerian Agama RI hanya ditemukan selisih maksimal tiga menit. Jika Di9ital Prayer Time dibandingkan dengan hasil program waktu salat karya Rinto Anugraha, hanya ditemukan selisih empat menit, akan tetapi setelah ditelusuri, program waktu salat Rinto belum menggunakan Ikhtiyat. Jika hasil program waktu salat Rinto ditambah dengan Ikhtiyat dua menit maka selisih maksimal dua menit. Dengan demikian, Di9ital Prayer Time sangat relevan dijadikan pedoman waktu salat. Sedangkan penentuan waktu salat oleh Kementerian Agama RI yang selama ini menjadi pedoman masyarakat di seluruh Indonesia masih relevan dijadikan pedoman waktu salat. Hal tersebut masih dalam batas kerelevanan, mengingat jadwal waktu salat oleh Kementerian Agama sangat membantu masyarakat.
\end{abstract}

Ulul Albab: Jurnal Studi dan Penelitian Hukum Islam 
Program Di9ital Prayer Time .... $\mid 61$

Kata Kunci: Waktu Salat. Di9ital Prayer Time. Tingkat Keakurasian

\section{Pendahuluan}

$1\left\{\begin{array}{l}\text { ementerian Agama Republik Indonesia telah berupaya } \\ \text { menyelesaikan problematika yang berkaitan dengan } \\ \text { penentuan waktu salat tersebut. Upaya tersebut yakni }\end{array}\right.$ dengan mengedarkan jadwal waktu salat sepanjang masa. Jadwal waktu salat sepanjang masa adalah jadwal yang bersifat umum di mana penentuannya berbeda setiap kota dan penentuannya tidak berdasarkan data koordinat dari setiap lokasi. ${ }^{1}$ Secara astronomis, konsep demikian tidak sesuai dengan konsep perhitungan waktu salat. Hal ini dikarenakan perhitungan awal waktu salat didasarkan pada garis edar matahari atau posisi matahari terhadap bumi yang setiap harinya juga pasti mengalami perubahan. ${ }^{2}$ Perubahan tersebut dikarenakan pengaruh musim atau pergerakan maya harian matahari terhadap bumi. Dengan demikian, hisab waktu salat pada dasarnya adalah menghitung waktu Matahari akan menempati posisi tertentu yang sekaligus menjadi penunjuk waktu salat. ${ }^{3}$

Melihat hal demikian, Hendro Setyanto membuat alat modern yang dapat digunakan dalam menentukan waktu salat. Alat ini dinamakan "Di9ital Prayer Time”. Alat ini merupakan tampilan waktu salat digital sepanjang masa. Digital ini diciptakan untuk memenuhi kebutuhan umat Islam dalam memberikan informasi waktu salat dengan mudah dan akurat. Di9ital Prayer Time dibuat algoritma astronomi yang

1 Departemen Agama RI, Pedoman Penentuan Jadwal Waktu Shalat Sepanjang Masa, Jakarta: Departemen Agama RI, 1994/1995, 43.

2 Encup Supriatna, Hisab Rukyat dan aplikasinya, (Bandung: Refika Aditama, 2007), 15

${ }^{3}$ Muslih Munawar, Penentuan Waktu Salat dan Menghitung Arah Kiblat, Bandung : Makalah disampaikan dalam acara Penataran Keterampilan Tenaga Hisab Rukyat, di Lingkungan Pengadilan Tinggi Agama, 1996. 
$62 \mid$ Fitriyani \& Syaifur Rizal Fahmy

memperkuat sejumlah faktor koreksi untuk memperoleh waktu salat yang tepat. ${ }^{4}$

Di9ital Prayer Time memiliki perbedaan konsep dibandingkan dengan jam digital yang lainnya. Di9ital Prayer Time dibuat dengan hasil yang bersifat lokal, di mana hasil penentuan waktu salat yang ditentukan jam digital ini didasarkan pada data lintang dan bujur lokasi serta ketinggian tempat setiap lokasi. Selain demikian terdapat koreksi internet menjadikan jam yang ditunjukkan lebih akurat, sehingga dapat memberikan solusi perbedaan dalam memulai waktu salat setiap masjid. ${ }^{5}$

Penelitian ini akan mengkaji tentang problematika waktu salat, gambaran umum tentang Di9ital Prayer Time karya Hendro Setyanto, metode dan cara kerja Di9ital Prayer Time karya Hendro Setyanto dalam menentukan waktu salat, dan tingkat akurasi Di9ital Prayer Time karya Hendro Setyanto dalam menentukan waktu salat. Berkiatan dengan tema tersebut, maka penelitian ini termasuk jenis penelitian kualitatif dengan menggunakan pendekatan yuridis empiris. Spesifikasi penelitian ini adalah deskriptif analisis, penelitian ini bermaksud untuk memberikan gambaran, menelaah, menjelaskan kemudian menganalisis tingkat akurasi Di9ital Prayer Time dalam penentuan waktu salat.

Penelitian ini menggunakan jenis data : pertama, data primer berupa wawancara terhadap Hendro Setyanto sebagai pencipta karya Di9ital Prayer Time dan praktik lapangan menentukan waktu salat menggunakan Di9ital Prayer Time.

${ }^{4}$ Wawancara terhadap Hendro Setyanto tentang gambaran umum Di9ital Prayer Time pada tanggal 05 Agustus 2016 di Imahnoong Lembang Bandung.

${ }^{5}$ Wawancara terhadap Hendro Setyanto tentang gambaran umum Di9ital Prayer Time pada tanggal 05 Agustus 2016 di Imahnoong Lembang Bandung.

Ulul Albab: Jurnal Studi dan Penelitian Hukum Islam 
Kedua, data Sekunder berupa buku, jurnal, dan sumber referensi lainnya yang mendukung penelitian tersebut.

\section{Problematika Waktu Salat di Indonesia}

Problematika yang terjadi di masyarakat khususnya umat Islam di Indonesia adalah problematika waktu salat. Satu titik yang letaknya berdekatan terkadang terdapat perbedaan dalam memulai waktu salat. Bahkan masjid sebagai pengingat masyarakat dalam memulai waktu salat terkadang terjadi ketidaktepatan dalam memulai waktu salat. Menurut Muhyiddin Khazin, perbedaan di antara jadwal-jadwal salat ini disebabkan antara lain oleh $:^{6}$

a. Perbedaan data koordinat yang dijadikan acuan.

Salat memiliki dimensi ruang dan waktu, di mana antara ruang satu dengan yang lain terdapat waktu salat yang berbeda. Perbedaan waktu salat antara titik satu dengan lainnya dalam satu wilayah hanya terdapat selisih pada detik. Hal demikian dikarenakan data koordinat dalam satu wilayah hanya terdapat selisih pada detik. Perbedaan tersebut tidak menjadi problematika waktu salat. Problematika waktu salat adalah ketika dalam satu daerah memiliki perbedaan waktu salat sampai selisih menit.

b. Perbedaan rumus perhitungan yang digunakan.

Perhitungan awal waktu salat yang biasa digunakan di Indonesia terdapat dua macam, diantaranya: pertama, perhitungan yang dijadikan pedoman oleh Kementerian Agama RI yaitu perhitungan menggunakan rumus yang tidak memperhitungkan ketinggian tempat. Kedua perhitungan dengan rumus yang menggunakan ketinggian tempat dari permukaan laut.

c. Perbedaan nilai ihtiyath.

6 Muhyiddin Khazin, 99 Tanya Jawab Masalah Hisab \& Rukyat, Yogyakarta: Ramadan Press, 45-46. 
64 Fitriyani \& Syaifur Rizal Fahmy

Para ahli hisab dalam menentukan waktu salat terdapat ketentuan ikhtiyath yang berbeda yakni menggunakan ikhtiyath 2 menit, 3 menit atau 4 menit. Para ahli Falak banyak menggunakan Ikhtiyath 2 menit dalam menentukan waktu salat. ${ }^{7}$ Hal demikian yang menyebabkan perbedaan dalam memulai waktu salat.

d. Perbedaan alat perhitungan yan digunakan.

Perhitungan awal waktu salat dapat dilakukan secara manual menggunakan bantuan kalkulator, atau dibantu dengan perangkat komputer yang telah di setting menjadi sebuah program. Perhitungan secara manual membutuhkan waktu yang lebih lama. Perhitungan secara manual sering dilakukan pembulatan atau penyederhanaan data untuk mempermudah perhitungan. Kalkulator dapat dugunakan untuk mempermudah perhitungan di mana data yang digunakan dalam bentuk bilangan desimal yang ditampilkan hanya sebesar digit dari kalkulator tersebut. Adapun perhitungan dengan perangkat komputer, dalam penyajian datanya memiliki ketelitian yang tinggi. ${ }^{8}$

e. Terdapat kesalahan dalam melakukan perhitungan dan data-data yang digunakan.

f. Kriteria atau opsi waktu salat yang berbeda.

Para ahi Falak juga berbeda pendapat dalam penentuan awal waktu salat Asar. Terdapat tiga pendapat tentang penentuan awal waktu Asar, sebagai berikut: ${ }^{9}$

a. Kelompok pertama menyatakan bahwa awal waktu Asar terkait dengan fenomena bayang-bayang suatu benda sama panjang dengan benda itu ditambah dengan bayang-bayang pada waktu Zuhur.

b. Kelompok kedua menyatakan bahwa awal waktu Asar terkait dengan fenomena bayang-bayang suatu benda dua

\footnotetext{
${ }^{7}$ Moh. Murtado, Ilmu Falak Praktis, (Malang: Uin Press, 2008), 193

${ }^{8}$ Muhyiddin Khazin, 99 Tanya Jawab Masalah Hisab..., 45.

${ }^{9}$ Muhyiddin Khazin, 99 Tanya Jawab Masalah Hisab..., 47.
} 
Program Di9ital Prayer Time .... $\mid 65$

kali panjang benda ditambah dengan bayang-bayang pada waktu Zuhur.

c. Kelompok ketiga menyatakan bahwa salat Asar adalah salat pertengahan. Waktu Asar itu adalah pertengahan antara salat Zuhur dan salat Magrib.

Kementerian Agama Republik Indonesia juga membuat jadwal waktu salat sepanjang masa. Kementerian Agama membuat jadwal waktu salat setiap kota di seluruh Indonesia yang dapat dijadikan sebagai panduan memulai salat. Hal demikian bertujuan untuk mempermudah masyarakat khususnya para takmir masjid dalam mengumandangkan salat.

Solusi demikian dapat membantu masyarakat dalam menunaikan salat. Faktor problematika waktu salat masih terjadi adalah terletak pada jam. Ketidaktepatan jam yang diterapkan mengakibatkan ketidaktepatan dalam memulai waktu salat. Faktor lainnya yang masih terjadi adalah penggunaan jadwal waktu salat abadi di mana beberapa masjid masih menggunakan pedoman jadwal jadwal waktu salat yang tidak sesuai dengan waktuya atau kadaluarsa. Sebagaimana diketahui bahwa konsep waktu salat berdasarkan waktu di mana setiap waktu maka jadwal waktu salatnya akan mengalami perubahan.

\section{Di9ital Prayer Time Karya Hendro Setyanto}

Di9ital Prayer Time merupakan jam digital yang diciptakan oleh Hendro Setyanto. Jam digital ini memberikan informasi waktu seperti jam digital pada umumnya. Perbedaan jam digital ini adalah jam selalu meng-update ke internet sehingga menghasilkan waktu yang akurat. Sebelum membahas tentang cara kerja dan tingkat akurasi dalam penentuan waktu salat, perlu di uraikan latar belakang penciptaan, konsep umum Di9ital Prayer Time dan juga fungsi umum Di9ital Prayer Time. 
66 Fitriyani \& Syaifur Rizal Fahmy

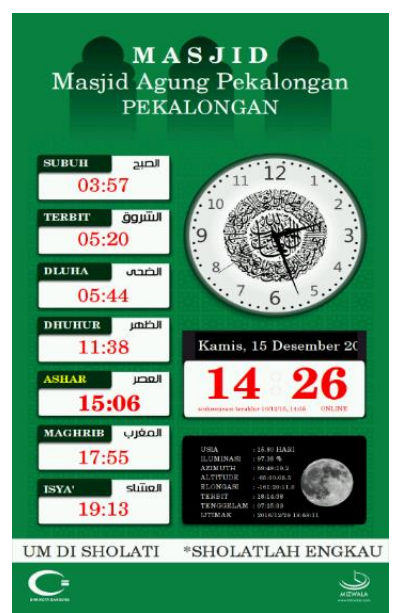

Tampilan gambar Di9ital Prayer Time. ${ }^{1}$

Alasan mendasar penciptakan program tersebut adalah untuk memenuhi kebutuhan masyarakat. Jam digital tersebut sangat membantu masyarakat dalam memulai waktu salat dan dapat mengurangi perbedaan dalam memulai salat dari beberapa masjid. Melihat perkembangan hidup manusia yang semakin bergantung pada hal-hal yang bersifat praktis dan instan. Dengan demikian, Di9ital Prayer Time sebagai jadwal waktu salat sepanjang masa yang lebih modern dan akurat. ${ }^{1}$

Konsep jadwal sepanjang masa pada umumnya adalah jadwal yang hanya menampilkan waktu selama satu tahun dari mulai Januari hingga Desember. Konsep selanjutnya adalah Hasib biasanya melakukan interpolasi antara 3-5 hari untuk efisiensi sehingga jadwal dapat dibuat dalam selembar data. Berbeda halnya dengan konsep waktu salat sepanjang masa pada Di9ital Prayer Time. Alat ini dapat memberikan jadwal

1 Tampilan Di9ital Prayer Time yang difoto langsuhg di Imahnoong Lembang Bandung pada 15 Juli 2016.

1 Wawancara terhadap Hendro Setyanto tentang gambaran umum Di9ital Prayer Time pada tanggal 05 Agustus 2016 di Imahnoong Lembang Bandung. 
waktu salat sepanjang masa dengan data koordinat yang bersifat lokal. Berkembangnya teknologi, Hendro membuat jadwal waktu salat sepanjang masa yang bersifat lokal. Digital dibuat dengan algoritma astronomi yang memperkuat sejumlah faktor koreksi untuk memperoleh waktu salat yang tepat. Jam digital ini didasarkan pada lintang dan bujur lokasi serta ketinggian tempat yang merupakan lokal sebuat tempat sehingga penentuan waktu ini bersifat lokal. ${ }^{1}$

Selain sebagai penentu waktu salat, Di9ital Prayer Time juga mempunyai fungsi diantaranya sebagai berikut $:^{1}$

a. Sebagai penentu jam yang akurat.

b. Sebagai penentu waktu salat yang akurat.

c. Memberikan data informasi tentang data bulan.

\section{Metode Di9ital Prayer Time dalam Penentuan Waktu Salat}

Metode akan menyangkut pada masalah cara kerja untuk memahami suatu objek yang menjadi suatu sasharan pengetahuan. Hal ini, metode adalah menemukan bagaimana cara membuat suatu alat dan menemukan bagaimana cara menggunakan alat yang telah berhasil dibuat.

Kemajuan teknologi mendorong Hendro Setyanto mengemas Software program waktu salat menjadi jam digital yang mampu memudahkan masyarakat dalam memulai waktu salat. Metode perhitungan yang digunakan Di9ital Prayer Time dalam perhitungan waktu salat tidak jauh berbeda dengan perhitungan waktu salat pada umumnya. Hal yang membedakan terletak pada pencarian data Deklinasi dan

1 Wawancara terhadap Hendro Setyanto tentang gambaran umum Di9ital Prayer Time pada tanggal 05 Agustus 2016 di Imahnoong Lembang Bandung.

1 Wawancara terhadap Hendro Setyanto tentang gambåran umum Di9ital Prayer Time pada tanggal 05 Agustus 2016 di Imahnoong Lembang Bandung. 
68| Fitriyani \& Syaifur Rizal Fahmy

Equation of Time. Jam digital ini menggunakan Julian Day atau Julian Date dalam mencari data Declination dan Equation of time.

Julian Day (JD) didefinisikan sebagai banyaknya hari yang telah dilalui sejak hari Senin tanggal 1 Januari tahun 4713 SM (= - 4712) pada pertengahan hari atau pukul 12:00:00 UT (Universal Time) atau GMT. Julian Day digunakan untuk memudahkan perhitungan yang berkaitan dengan tanggal dan penentuan posisi benda langit (Bulan dan Matahari), kemiringan orbit rotasi bumi, menghitung waktu terjadinya equinoks, solstice, dan sebagainya. Jika dikaitkan dengan perhitungan waktu salat, Julian Day atau Julian Date digunakan untuk mencari Deklinasi Matahari dan Equation of Time. ${ }^{1}$

Pengukuran astronomi yang penting adalah persamaan waktu (Equation of Time) dan Deklinasi matahari. Persamaan waktu adalah perbedaan antara waktu yang dibaca dari jam matahari dengan jam biasa. Nilai yang muncul berasal dari pergerakan matahari yang tidak teratur yang tampak disebabkan oleh kombinasi sumbu rotasi bumi dan eksentrisitas dari orbitnya. Sebuah jam matahari dapat lebih cepat sekitar 16 menit 33 detik (pada sekitar tanggal 3 November) atau lebih lambat sekitar 14 menit 6 detik (pada sekitar tanggal 12 Februari). Deklinasi matahari adalah sudut antara sinar matahari dan permukaan bumi pada garis katulistiwa. Deklinasi matahari berubah secara teratur sepanjang tahun. Ini merupakan konsekuensi dari kemiringan bumi, yakni perbedaan antara sumbu rotasi dan revolusi bumi. ${ }^{1}$

Hal mendasar dari perhitungan Julian Day diawali dari data basic (input data) antara lain data jam, menit, detik, zona waktu, hari, bulan, dan tahun yang kemudian dihitung dengan menggunakan rumus Julian Day. Rumus Julian Day memiliki

\footnotetext{
1 www.prayertime.org. Hasil informasi Hendro Setyanto saat wawancara pada tanggal 15 Agustus 2016 di Imahnoong Wangunsari Lembang Bandung Barat yang diakses pada tanggal 11 Desember 2016 Pukul 20.30

1 www.prayertime.org.
} 
Program Di9ital Prayer Time .... $\mid 69$

banyak macam, di antaranya memakai algoritma Jeen Meeus dan sebagainya. Sedangkan Di9ital Prayer Time menggunakan algoritma AS Naval Observatory. ${ }^{1}$

AS Naval Observatory adalah otoritas terkemuka di bidang pencatat waktu dan mengamati langit; menentukan dan mendistribusikan waktu dan data astronomi yang diperlukan untuk navigasi yang akurat dan astronomi mendasar. Algoritma ini merupakan publikasi Nautical Almanac Office Ratu (HMNAO) dari Inggris. Perangkat lunak NavPac, disediakan pada CDROM, memungkinkan navigator untuk dengan mudah menghitung posisi mereka di laut dari pengamatan yang dilakukan dengan sextant. ${ }^{1}$

Berikut adalah algoritma dari U.S. Naval Observatory untuk menghitung koordinat sudut matahari dengan akurasi sekitar 1 arcminute dalam waktu dua abad terakhir :1

d $\quad=j d-2451545.0 ; / /$ Jd adalah

Penanggalan Julian

$$
\begin{array}{ll}
\mathrm{g} & =357.529+0.98560028^{*} \mathrm{~d} ; \\
\mathrm{q} & =280.459+0.98564736^{*} \mathrm{~d} ; \\
\mathrm{L} & =\mathrm{q}+1.915^{*} \sin (\mathrm{g})+0.020^{*} \sin \left(2^{*} \mathrm{~g}\right) ; \\
\mathrm{R} & =1.00014-0.01671^{*} \cos (\mathrm{g})-0.00014^{*}
\end{array}
$$

$\cos \left(2^{*} \mathrm{~g}\right)$

$$
\begin{array}{ll}
\mathrm{e} & =23.439-0.00000036^{*} \mathrm{~d} ; \\
\mathrm{RA} & =\arctan 2\left(\cos (\mathrm{e})^{*} \sin (\mathrm{L}), \cos (\mathrm{L})\right) / 15 \\
\mathrm{D} & =\arcsin \left(\sin (\mathrm{e})^{*} \sin (\mathrm{L})\right) ; / / \text { Deklinasi }
\end{array}
$$

Matahari

$$
\text { EqT }=\mathrm{q} / 15-\mathrm{RA} ; / / \text { equation of time }
$$

\footnotetext{
1 www.prayertime.org.

${ }^{1}$ http://www.usno.navy.mil/USNO/astronomical- 7
} applications/software-products. Diakses pada tanggal 18 Desember 2016 Pukul 20.22 .

1 www.prayertime.org. Hasil informasi Hendro Setyanto saat wawancara pada tanggal 15 Agustus 2016 di Imahnoong Wangunsari Lembang Bandung Barat yang diakses pada tanggal 11 Desember 2016 Pukul 20.30 
70| Fitriyani \& Syaifur Rizal Fahmy

Langkah selanjutnya adalah menghitung waktu salat. Untuk menghitung waktu salat di tempat tertentu, diperlukan pengetahuan terkait data Lintang Tempat dan Bujur Tempat dari lokasi tersebut, serta Local Time Zone untuk lokasi bersangkutan. Selain itu juga dibutuhkan Equation of Time (EqT) dan Deklinasi Matahari (D) untuk tanggal yang ada menggunakan algoritma yang disebutkan sebelumnya. Berikut adalah rumus penentuan waktu shalat : 1

a. Zhuhur dapat dihitung dengan rumus sebagai berikut:

Zhuhur = 12 + TimeZone - Lng/15 - EqT .

b. Matahari Terbit dan Matahari Tenggelam

Dapat dihitung dengan rumus sebagai berikut :

$$
T(\alpha)=\frac{1}{15} \arccos \left(\frac{-\sin (\alpha)-\sin (L) \sin (D)}{\cos (L) \cos (D)}\right)
$$

Matahari Terbit dan Tenggelam secara astronomis terjadi pada saat $\alpha=0$. Namun, adanya pembiasaan cahaya pada wilayah atmosfer mengakibatkan matahari terbit sesungguhnya bergeser ke waktu sebelum perhitungan astronomis dan matahari tenggelam bergeser ke waktu setelah yang diperoleh dari perhitungan astronomis. Waktu matahari terbit dan tenggelam sesungguhnya dapat dihitung dengan rumus berikut:

Matahari Terbit $=$ Zhuhur $-\mathrm{T}(\mathbf{0 . 8 3 3})$

Matahari Tenggelam $=$ Zhuhur $+\mathrm{T}(0.833)$

Jika lokasi pengamat lebih tinggi dari daerah sekitarnya, kita dapat mempertimbangkan sudut ini dengan menambah konstanta 0,833 diatas dengan $0.0347 \times \operatorname{sqrt}(\mathrm{h})$, di mana $\mathrm{h}$ adalah tinggi tempat pengamatan dalam satuan meter.

c. Fajar dan Isya'

Beberapa pendapat berbeda tentang sudut yang digunakan untuk menghitung Fajar dan Isya. Sebagai contoh,

1 www.prayertime.org. 
menurut konvensi Muslim World League, Fajar = Zhuhur $-\mathrm{T}(18)$ dan Isya $=$ Zhuhur $+\mathrm{T}(17)$.

d. Ashar

Di bawah ini merupakan rumus mencari awal waktu Ashar :

$$
A(t)=\frac{1}{15} \arccos \left(\frac{\sin (\operatorname{arccot}(t+\tan (L-D)))-\sin (L) \sin (D)}{\cos (L) \cos (D)}\right)
$$

e. Maghrib

Berdasarkan pandangan Sunni, waktu untuk salat Maghrib dimulai saat matahari telah tenggelam total di horison, jadi, Maghrib = Matahari Tenggela (beberapa perhitungan menyarankan 1 hingga 3 menit setelah matahari tenggelam untuk berhati-hati). Pandangan Syiah, pendapat yang dominan adalah bahwa selama langit masih berwarna merah setelah matahari terbenam, salat maghrib belum bisa dimulai. Biasanya yang di masukkan ke dalam pertimbangan perhitungan adalah dengan memasukkan sudut senja dengan Maghrib=Zhuhur+(4).

\section{Tingkat Keakurasian Di9ital Prayer Time}

Berdasarkan pertimbangan data matahari yang digunakan mengakibatkan tidak banyak perubahan waktu salat dalam setiap waktu, maka sebuah jadwal waktu salat dapat diberlakukan sepanjang masa. Hal demikian didukung oleh pendapat Slamet Hambali yang menyatakan bahwa perbedaan nilai deklinasi matahari dan equation of time dari tahun ke tahun itu sangat kecil dan pengaruh dalam perhitungan waktu salat pun tidak terlalu jauh. ${ }^{2}$ Thomas Djamaluddin juga menjawab ${ }^{0}$ dengan hal yang sama (Posisi Matahari relatif tidak banyak berubah. Jadi data posisi Matahari pada 1966 M hampir sama

2 Nila Soraya, Uji Akurasi Pedoman Waktu Salat Sepdnjang Masa Karya Saadoeddin Djambek, Skripsi Program Studi Ilmu Falak Fakultas Syari'ah dan Ekonomi Islam, 2012, 98. 
$72 \mid$ Fitriyani \& Syaifur Rizal Fahmy

dengan tahun $2013 \mathrm{M}$ untuk ketelitian sampai orde menit) ketika ditanya mengenai hal itu. ${ }^{2}$

Analisis tingkat akurasi Di9ital Prayer Time dalam penelitian ini akan mencoba membandingkan hasil penentuan waktu salat yang ditentukan oleh Di9ital Prayer Time dengan jadwal waktu salat yang diedarkan oleh Kementerian Agama RI dan hasil program waktu salat yang dibuat oleh Dr. Rinto Anugraha .

1. Jadwal Waktu Salat Edaran Kementerian Agama

Jadwal waktu salat edaran Kementerian Agama dengan Di9ital Prayer Time memiliki kesamaan yakni jadwal waktu salat sepanjang masa. Selain itu, Kementerian Agama juga merupakan sebuah lembaga yang terpercaya dan jadwal waktu salat sudah dijadikan sebagai pedoman waktu salat seluruh Indonesia.

Di9ital Prayer Time dan Kementerian Agama RI memiliki perbedaan konsep dalam menentukan waktu salat. Di9ital Prayer Time karya Hendro Setyanto ini merupakan jam digital sepanjang masa, di mana jam demikian didasarkan pada lintang dan bujur lokasi serta ketinggian tempat yang merupakan lokal sebuat tempat. Penentuan waktu ini bersifat lokal dan hanya bisa dijadikan pedoman waktu salat oleh suatu lokal itu. Kementerian Agama RI menentukan waktu salat secara global di mana satu jadwal waktu salat dapat dijadikan seluruh masyarakat setiap kota masing-masing.

2. Program Waktu Salat yang dibuat oleh Dr. Rinto Anugraha.

Selain membandingkan dengan hasil penentuan Kementerian Agama RI, penulis juga membandingkan dengan hasil program waktu salat yang dibuat oleh Rinto Anugraha. Rinto Anugraha adalah salah satu ahli Fisika dan astronomi di Indonesia. Selain demikian, program waktu salat yang dibuat oleh Rinto memiliki kesamaan konsep

22 Nila Soraya, Uji Akurasi Pedoman..., 98 
Program Di9ital Prayer Time .... $\mid 73$

dengan Di9ital Prayer Time yaitu menggunakan data koordinat dan ketinggian tempat lokal. Hal ini dianggap perlu karena sebagai penguat dalam menganalisis tingkat keakurasian Di9ital Prayer Time karya Hendro Setyanto. Penulis juga menggunakan data koordinat yang sama antara Di9ital Prayer Time dengan program waktu salat yang dibuat oleh Rinto Anugraha.

Berikut ini adalah contoh hasil perbandingan penentuan waktu salat antara Di9ital Prayer Time, jadwal waktu salat yang diedarkan oleh Kementerian Agama RI dan hasil program waktu salat yang dibuat oleh Dr. Rinto Anugraha pada Kamis, 15 Desember 2016 yang ditentuan Di9ital Prayer Time karya Hendro Setyanto dan Kementerian Agama RI:

\begin{tabular}{|c|c|c|c|c|c|c|c|}
\hline \multicolumn{8}{|c|}{ SURAKARTA } \\
\hline & Shubuh & Terbit & Dhuha & Zhuhur & Ashar & Maghrib & Isya' \\
\hline $\begin{array}{l}\text { Di9ital } \\
\text { Prayer Time } \\
\text { Kementerian } \\
\text { Agama RI } \\
\text { Selisih }\end{array}$ & $\begin{array}{l}03.53 \\
03.51 \\
00.02\end{array}$ & $\begin{array}{l}05.15 \\
05.12 \\
00.03\end{array}$ & $\begin{array}{l}05.40 \\
05.40 \\
00.00\end{array}$ & $\begin{array}{l}11.34 \\
11.35 \\
00.01\end{array}$ & $\begin{array}{l}15.01 \\
15.01 \\
00.00\end{array}$ & $\begin{array}{l}17.51 \\
17.52 \\
00.01\end{array}$ & $\begin{array}{l}19.08 \\
19.08 \\
00.00\end{array}$ \\
\hline $\begin{array}{l}\text { Di9ital } \\
\text { Prayer Time } \\
\text { Program } \\
\text { Dr.Rinto } \\
\text { Selisih }\end{array}$ & $\begin{array}{l}03.53 \\
03.49 \\
00.04\end{array}$ & $\begin{array}{l}05.15 \\
05.14 \\
00.01\end{array}$ & $\begin{array}{c}05.40 \\
- \\
-\end{array}$ & $\begin{array}{l}11.34 \\
11.32 \\
00.02\end{array}$ & $\begin{array}{l}15.01 \\
14.59 \\
00.02\end{array}$ & $\begin{array}{l}17.51 \\
17.50 \\
00.01\end{array}$ & $\begin{array}{l}19.08 \\
19.06 \\
00.02\end{array}$ \\
\hline
\end{tabular}


74 $\mid$ Fitriyani \& Syaifur Rizal Fahmy

\begin{tabular}{|c|c|c|c|c|c|c|c|}
\hline \multicolumn{8}{|c|}{ PEKALONGAN } \\
\hline & Shubuh & Terbit & Dhuha & Zhuhur & Ashar & Maghrib & Isya' \\
\hline $\begin{array}{l}\text { Di9ital } \\
\text { Prayer Time } \\
\text { Kementerian } \\
\text { Agama R1 } \\
\text { Selisih }\end{array}$ & $\begin{array}{l}03.57 \\
03.57 \\
00.00\end{array}$ & $\begin{array}{l}05.20 \\
05.18 \\
00.02\end{array}$ & $\begin{array}{l}05.44 \\
05.46 \\
00.02\end{array}$ & $\begin{array}{l}11.38 \\
11.39 \\
00.01\end{array}$ & $\begin{array}{l}15.06 \\
15.06 \\
00.00\end{array}$ & $\begin{array}{l}17.55 \\
17.55 \\
00.00\end{array}$ & $\begin{array}{l}19.13 \\
19.11 \\
00.02\end{array}$ \\
\hline $\begin{array}{l}\text { Di9ital } \\
\text { Prayer Time } \\
\text { Dr. Rinto } \\
\text { Anugraha } \\
\text { Selisih }\end{array}$ & $\begin{array}{l}03.57 \\
03.55 \\
00.02\end{array}$ & $\begin{array}{l}05.20 \\
05.20 \\
00.00\end{array}$ & $\begin{array}{c}05.44 \\
- \\
-\end{array}$ & $\begin{array}{l}11.38 \\
11.37 \\
00.01\end{array}$ & $\begin{array}{l}15.06 \\
15.04 \\
00.02\end{array}$ & $\begin{array}{l}17.55 \\
17.53 \\
00.02\end{array}$ & $\begin{array}{l}19.13 \\
19.09 \\
00.04\end{array}$ \\
\hline
\end{tabular}

Beberapa contoh penentuan waktu salat Di9ital Prayer Time karya Hendro Setyanto dengan jadwal waktu salat edaran Kementerian Agama RI dan hasil program waktu salat yang dibuat oleh Dr. Rinto Anugraha di atas menunjukkan bahwa tidak terdapat perbedaan yang signifikan dari adanya selisih hasil komparasi tersebut. Berdasarkan hasil komparasi hanya terdapat selisih maksimal tiga menit jika dibandingkan dengan jadwal waktu salat edaran Kementerian Agama RI. Apabila dibandingkan hasil program waktu salat Rinto Anugraha, hanya terdapat selisih empat menit. Namun, program waktu salat Rinto Anugraha belum menggunakan Ikhtiyat. Apabila hasil program waktu salat Rinto Anugraha ditambah dengan Ikhtiyat dua menit maka hanya terdapat selisih maksimal dua menit. Hal demikian menunjukkan bahwa perbedaan data tidak terlalu mempengaruhi hasil perhitungan penentuan waktu salat. Bahkan hasil dari setia[ program tersebut telah disikapi dengan adanya penggunaan ikhtiyat atau kehati-hatian 2 menit. 
Berdasarkan pemaparan di atas, maka Di9ital Prayer Time sangat relevan digunakan pedoman waktu salat. Hal demikian dikarena perhitungan awal waktu salat didasarkan pada garis edar matahari atau posisi matahari terhadap bumi yang setiap harinya juga pasti mengalami perubahan. ${ }^{2}$ Perubahan tersebut dipengaruhi oleh musim atau pergerakan maya harian matahari terhadap bumi. Oleh karena itu, menghisab waktu salat pada dasarnya adalah menghitung kapan matahari akan menempati posisi tertentu yang sekaligus menjadi penunjuk waktu salat. ${ }^{2}$ Akibatnya penentuan waktu salat ditentukan sesuai dengan data koordinat masing-masing lokal atau titik.

Ketinggian tempat juga dapat mempengaruhi tingkat keakurasian waktu Maghrib dan Terbit. Perhitungan waktu salat Maghrib akan berpengaruh pada Isya' sedangkan Terbit akan berpengaruh pada Shubuh. Walaupun hasil komparasi hanya selisih maksimal tiga menit.

Salah satu faktor penyebab ketidaktepatan waktu salat adalah jam yang kurang tepat. Jam digital ini setiap dua hingga lima menit selalu meng-update ke internet sehingga menghasilkan waktu hakiki yang lebih akurat. Secara otomatis waktu salat yang dihasilkan semakin akurat dan tepat. Sebuah jam digital yang dibuat dengan konsep sepanjang masa ini mempermudah masyarakat dalam menentukan waktu salat. Di mana satu alat dan bahkan dalam satu tempat, alat ini mampu menghasilkan waktu salat dimanapun titik yang hendak dicari sesuai dengan data koordinat masing-masing.

Jadwal waktu salat edaran Kementerian Agama RI yang selama ini menjadi pedoman masyarakat di seluruh Indonesia masih relevan dijadikan pedoman waktu salat. Walaupun secara teori astronomi, hal demikian sangat mempengaruhi keakuratan

2 Encup Supriatna, Hisab Rukyat dan aplikasinya..., $15 . \quad 2$

2 Muslih Munawar, Penentuan Waktu Salat..., 56. 
$76 \mid$ Fitriyani \& Syaifur Rizal Fahmy

waktu salat yang telah ditentukan akan tetapi hasil komparasi hanya terdapat selisih maksimal tiga menit. Sedangkan dalam Ikhtiyat ada yang berpendapat dua, tiga atau empat menit. Dengan demikian, jadwal waktu salat edaran Kementerian Agama RI masih dalam batas kerelevanan. Mengingat adanya jadwal waktu salat tersebut sangat membantu masyarakat dalam memulai waktu salat dan dapat mengurangi perbedaan dalam memulai salat dari beberapa masjid. Menurut penulis, tidak semua jadwal waktu salat sepanjang masa bisa dijadikan sebagai pedoman. Beberapa hal yang harus diperhatikan dalam menggunakan pedoman jadwal waktu salat sepanjang masa, di antaranya : ${ }^{2}$

a) Jadwal salat merupakan jadwal yang dihitung untuk suatu kota dengan berdasarkan koordinat yang benar; disepakati.

b) Jadwal yang baik yang dihitung secara khusus untuk suatu kota.

c) Tidak melakukan koreksian kota atau daerah yang lain.

d) Kalangan ahli Falak, maka sebaiknya tidak menggunakannya.

e) Jadwal tersebut selayaknya dikeluarkan oleh pihak yang berwenang.

Hasil waktu salat Kementerian Agama RI merupakan hasil waktu salat sepanjang masa yang penuh dengan pertimbangan karena dalam pasal menegaskan bahwa Kementerian Agama harus bisa memberikan sebuah pedoman waktu salat bagi masyarakat. Selain demikian, Kementerian Agama RI juga melakukan beberapa pengecekan, di antaranya $:^{2}$

a) Untuk pengecekan waktu Zhuhur dilakukan dengan menggunakan transit theodolit atau tongkat istiwa'.

2 http://kasmui.com/v1/?p=4358, diakses pada 074 September 2016 Pukul 22.39.

2 Departemen Agama RI, Pedoman Penentuan JadwaF..., 51-53. 
Program Di9ital Prayer Time .... $\mid 77$

b) Untuk pengecekan waktu Ashar dapat dilakukan menggunakan tongkat istiwa' yaitu dengan mencatat panjang bayang-bayang waktu zhuhur dengan menjumlahkan panjang tongkat.

c) Untuk pengecekan waktu Maghrib dan akhir Shubuh yaitu saat matahari terbit dan tenggelam.

d) Untuk pengecekan waktu Isya harus diperhatikan berulangulang kali karena harus memperhatikan hilangnya mega merah di bawah Ufuk Barat.

Dari seluruh pemaparan di atas, maka Di9ital Prayer Time merupakan jam digital sepanjang masa yang dapat menghasilkan waktu salat yang sangat akurat sehingga sangat relevan dijadikan pedoman masyarakat. Melihat selisih hasil waktu salat antara Di9ital Prayer Time dengan Kementerian Agama RI maksimal tiga menit, maka hasil Kementerian Agama masih dalam batas kerelevanan jika dijadikan pedoman masyarakat. Mengingat jadwal tersebut sangat membantu masyarakat dalam menunaikan ibadah salat.

\section{Penutup}

Di9ital Prayer Time karya Hendro Setyanto merupakan Sebuah program excel penentuan waktu salat sehingga dengan memanfaatkan kemajuan teknologi, Hendro Setyanto mengemas Software ini menjadi jam digital yang mampu memudahkan masyarakat dalam memulai waktu salat. Metode perhitungan yang digunakan dalam perhitungan waktu salat tidak jauh berbeda dengan perhitungan waktu salat pada umumnya. Hal yang membedakan terletak pada pencarian data Deklinasi dan Equation of Time. Jam digital ini menggunakan Julian Day atau Julian Date dalam mencari data Declination dan Equation of time. Di9ital Prayer Time menggunakan algoritma AS Naval Observatory.

Hasil komparasi antara Di9ital Prayer Time dan waktu salat edaran Kementerian Agama RI hanya ditemukan selisih 
78| Fitriyani \& Syaifur Rizal Fahmy

menit bahkan hanya ditemukan selisih maksimal tiga menit. Jika dibandingkan hasil waktu salat program Rinto, hanya ditemukan selisih empat menit. Namun, setelah ditelusuri, program Rinto belum menggunakan Ikhtiyat. Jika hasil waktu salat program Rinto ditambah dengan Ikhtiyat dua menit maka selisih maksimal dua menit. Dengan demikian, Di9ital Prayer Time masih relevan dijadikan sebagai pedoman waktu salat. Sedangkan penentuan waktu salat oleh Kementerian Agama RI yang selama ini menjadi pedoman masyarakat di seluruh Indonesia masih dalam batas kerelevanan jika dijadikan pedoman waktu salat. Walaupun tidak sesuai dengan konsep perhitungan waktu salat akan tetapi berdasarkan hasil komparasi hanya menemukan selisih maksimal tiga menit. Mengingat adanya jadwal waktu salat tersebut sangat membantu masyarakat dalam memulai waktu salat dan dapat mengurangi perbedaan dalam memulai salat.

Berdasarkan pada kesimpulan di atas, maka rekomendasi yang dihasilkan dari kajian ini sebagai berikut: Pertama, perlu adanya penyederhanaan Di9ital Prayer Time sehingga pemasangan perangkatnya lebih mudah.Kedua, Masjid atau Mushola dianggap perlu untuk menggunakan Di9ital Prayer Time. Ketiga, Kementerian Agama dianggap perlu untuk memperhatikan masyarakat yang menggunakan jadwal waktu salat yang dianggap tidak relevan digunakan sebagai panduan waktu salat atau bahkan jadwal waktu salat yang tidak sesuai waktunya.

\section{Daftar Pustaka}

Departemen Agama RI. 1994/1995. Pedoman Penentuan Jadwal Waktu Shalat Sepanjang Masa, Jakarta: Departemen Agama RI.

Khazin, Muhyiddin. 2009. 99 Tanya Jawab Masalah Hisab E Rukyat. Yogyakarta: Ramadan Press.

Murtado, Moh. 2008. Ilmu Falak Praktis. Malang: Uin Press. 
Supriatna, Encup. 2007. Hisab Rukyat dan aplikasinya. Bandung: Refika Aditama.

Muslih Munawar. Penentuan Waktu Salat dan Menghitung Arah Kiblat. Bandung : Makalah disampaikan dalam acara Penataran Keterampilan Tenaga Hisab Rukyat, di Lingkungan Pengadilan Tinggi Agama.

Nila Soraya. 2012. Uji Akurasi Pedoman Waktu Salat Sepanjang Masa Karya Saadoeddin Djambek. Skripsi Program Studi Ilmu Falak Fakultas Syari'ah dan Ekonomi Islam.

Wawancara terhadap Hendro Setyanto tentang gambaran umum Di9ital Prayer Time pada tanggal 05 Agustus 2016 di Imahnoong Lembang Bandung.

www.prayertime.org.

http://www.usno.navy.mil/USNO/astronomicalapplications/software-products.

http://kasmui.com/v1/?p=4358 